\title{
Permanent Mandibular Incisor with Multiple Anomalies - Report of a Rare Clinical Case
}

\author{
Nayaka Basavanthappa NAGAVENI ${ }^{1}$ \\ Kagathur Veerbadrapa UMASHANKARA ${ }^{2}$ \\ B.G. VIDYULLATHA ${ }^{3}$ \\ SREEDEVI ${ }^{3}$ \\ Nayaka Basavanthappa RADHIKA ${ }^{4}$
}

\begin{abstract}
${ }^{1}$ Department of Pedodontics and Preventive Dentistry, Hitkarini Dental College and Hospital, Jabalpur, Madhya Pradesh, India

${ }^{2}$ Department of Oral and Maxillofacial Surgery, Hitkarini Dental College and Hospital, Jabalpur, Madhya Pradesh, India ${ }^{3}$ Department of Oral Medicine and Radiology, Hitkarini Dental College and Hospital, Jabalpur, Madhya Pradesh, India ${ }^{4}$ Department of Orthodontics and Dentofacial Orthopedics, School of Dentistry, Krishna Institute of Medical Sciences, Satara district, Karad, Maharashtra, India
\end{abstract}

\begin{abstract}
Permanent mandibular central incisor is rarely affected by tooth shape anomalies of crown and root. Co-occurrence of multiple anomalies in a permanent mandibular central incisor is extremely rare. This paper reports an unusual concurrent combination of multiple dental anomalies affecting both the crown and root of a permanent mandibular left central incisor - talon cusp, dens invaginatus, short root anomaly and macrodontia -, which has not previously been reported together. Case management is described and implications are discussed. The dentist should be aware of these rare entities in order to provide an accurate diagnosis and management for which detailed examination of the tooth both clinically and radiographically is very important.
\end{abstract}

Key Words: anomalies, dens invaginatus, mandibular incisor, short root anomaly, talon cusp.

\section{INTRODUCTION}

Morphological variations of dental structure involving either crown or root are common in the literature. Talon cusp is a relatively rare developmental anomaly of tooth shape. It has been defined as an additional cusp that projects predominantly from the labial or lingual surface of primary or permanent anterior teeth (1). It extends at least half the distance from the cementoenamel junction (CEJ) to the incisal edge. The majority of cases of talon cusp (92\%) occur in the maxilla and are distributed as 55\% in lateral incisors, $32 \%$ in central incisors and $9 \%$ in canines (1). It is rarely seen in mandibular teeth. The exact etiology is unknown. It has been reported that talon cusp may occur as a result of abnormal proliferation of inner enamel epithelial cells and transient focal hyperplasia of the peripheral cells of mesenchymal dental papilla at the morpho- differentiation stage of tooth development (2).

Dens invaginatus is also a rare developmental anomaly defined as a deep surface invagination of the crown or root, which is lined by enamel and resulting from the invagination of the enamel organ into the dental papilla during odontogenesis (3). It is also known as 'dens in dente' or 'dilated composite odontoma'. The prevalence of this anomaly has been found to range from $0.25 \%$ to $5.1 \%$ of the population (3). It is seen predominantly in the maxilla and the most commonly affected tooth is the maxillary lateral incisor, followed by the maxillary central incisor, premolar, canine and molar (3). It usually occurs unilaterally, but bilateral cases have also been reported (4). Occurrence of dens invaginatus in mandibular teeth is very rare. Several theories have been proposed to explain the etiology of dens invaginatus. It has been stated that the invagination could be a result of rapid and aggressive proliferation of a

Correspondence: Dr. N.B. Nagaveni, Department of Pedodontics and Preventive Dentistry, Hitkarini Dental College and Hospital, Jabalpur - 482005, Madhya Pradesh, India. Tel: +91-9589866445, e-mail:nagavenianurag@gmail.com 
part of the internal enamel epithelium invading the dental papilla (3). Other factors like injury or infection have also been mentioned as possible causes. However, the exact etiology of dens invaginatus is still controversial.

Short root anomaly (SRA), described first by Lind (5) in 1972, is defined as developmentally very short, blunt dental roots. Root that is equal to or shorter than the crown size is considered as SRA. This condition most commonly affects both maxillary central incisors almost symmetrically (5). Premolars and canines are rarely involved (5). Extensive review of literature failed to reveal SRA affecting only mandibular incisor.

Macrodontia also called as 'megalodontia' or 'megadontia' is the term applied only when teeth are physically larger than usual. Macrodontia of single tooth is relatively uncommon, but it is occasionally seen and is of unknown etiology (6). The tooth may appear

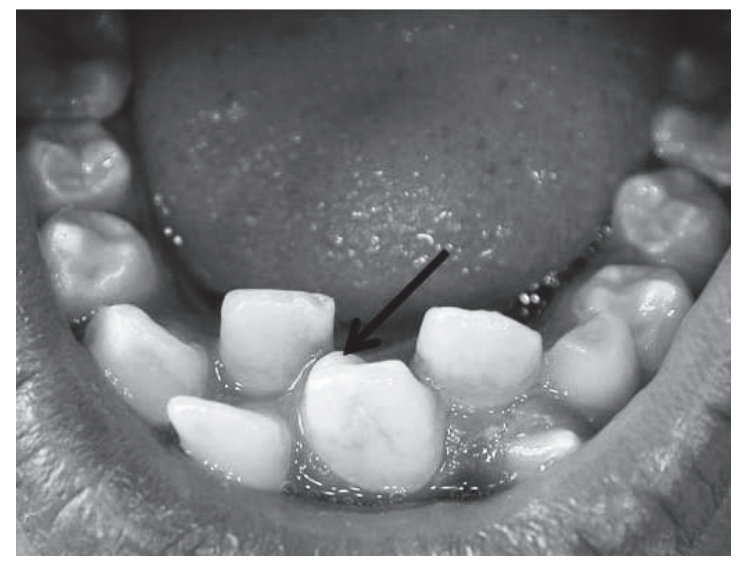

Figure 1. Mandibular left central incisor with abnormal crown morphology. Talon cusp is evident on lingual surface (arrow).

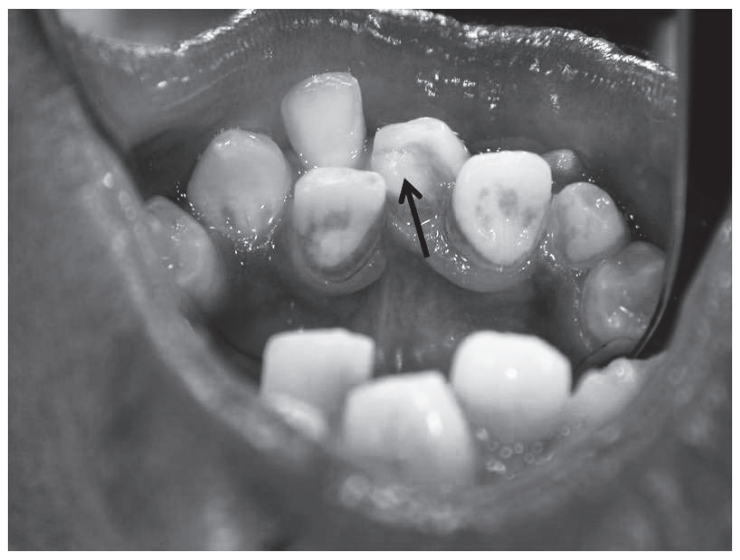

Figure 2. Mirror view of talon cusp on lingual surface of mandibular left central incisor (arrow). normal in every aspect except for its size. Macrodontia of only mandibular central incisor is a rare occurrence.

Although co-occurrence of talon cusp and dens invaginatus has been reported (7-13), their occurrence together with other anomalies like macrodontia and short root anomaly in the same tooth has never been reported.

This paper reports an unusual concurrent combination of multiple dental anomalies - talon cusp, dens invaginatus, short root anomaly and macrodontia - affecting both the crown and root of the permanent mandibular left central incisor of a 12-year-old Indian boy.

\section{CASE REPORT}

A 12-year-old male patient reported complaining of irregularly placed mandibular anterior teeth. Intraoral examination revealed mixed dentition with poor oral hygiene.

He had Class I molar relation and crowding of mandibular anterior teeth. There were no apparent manifestations of any systemic, genetic and syndromic disorders. Patient family history was non-contributory. The permanent mandibular left central incisor appeared larger in size with different crown morphology as compared with the contralateral incisor (Fig. 1). Talon cusp was observed on the lingual surface of the same tooth which was extending to the incisal third (Fig. 2).

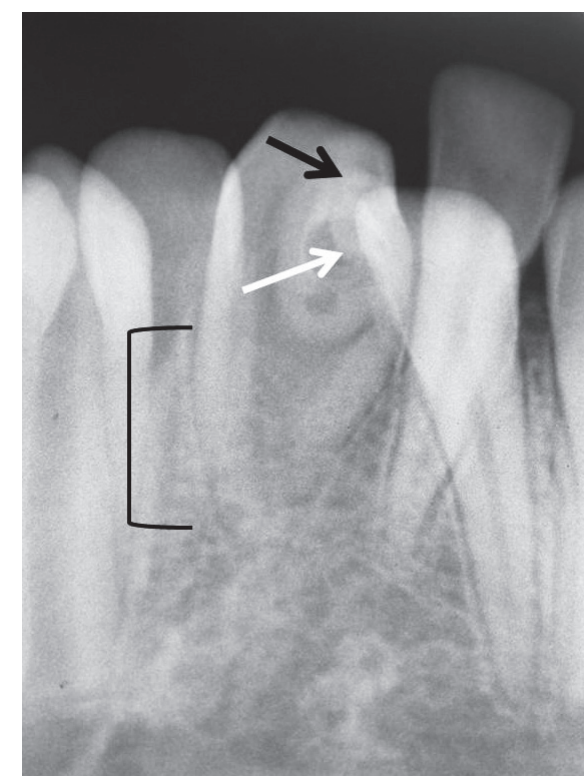

Figure 3. Periapical radiograph showing talon cusp (black arrow), dens invaginatus (white arrow) and short root (bracket). Note length of the root is almost equal to length of the crown. 
Examination of periapical radiograph confirmed the talon cusp (Fig. 3). Detailed visualization of the same radiograph revealed presence of dens invaginatus within the talon cusp and the root of the same tooth was very short and blunt (Fig. 3). The length of the root was almost equal to that of crown length and was shorter compared with roots of adjacent teeth (Fig. 3). The border of the dens invaginatus was distinct with an opaque rim similar to radiodensity of enamel. The tooth was vital and no apical rarefaction was noticed. Finally, the case was diagnosed as tooth associated with multiple anomalies i.e., talon cusp (Type 1), dens invaginatus (Type 1), short root anomaly and macrodontia. As the patient was not having any other problems associated with this tooth only sealing of developmental groove was done for caries prevention. The patient was then referred to the Orthodontics Department for correction of tooth crowding.

\section{DISCUSSION}

Concurrent occurrence of two anomalies in a single tooth is reported in the literature (7-15), but single tooth affected with three or four dental anomalies involving both crown and root is not reported in the literature.

Although talon cusp and dens invaginatus can occur as an isolated finding, they may sometimes occur together with other tooth anomalies. Talon cusp with peg-shaped lateral incisors, agenesis of canines, mesiodens, complex odontoma or megadont has been published (3). In case of dens invaginatus, there are reports about the concomitant presence of dens invaginatus with other tooth anomalies, such as microdontia, macrodontia, taurodontism, amelogenesis imperfecta and dentinogenesis imperfecta. However, the occurrence of both talon cusp and dens invaginatus in a single tooth is extremely rare. Until now, to the best of authors' knowledge, only eight cases have been reported in the dental literature (Medline/PUBMED search) (714) (Table 1). Among these eight cases, seven cases have been reported in the maxilla and one case in the mandible. In the maxilla, involved teeth were central and lateral incisors and in case of mandible affected

Table 1. Reported cases of co-occurrence of talon cusp and dens invaginatus in a single tooth.

\begin{tabular}{|c|c|c|c|c|c|}
\hline Author and year & $\begin{array}{l}\text { Affected } \\
\text { arch }\end{array}$ & Affected tooth & $\begin{array}{l}\text { Talon cusp } \\
\text { type }\end{array}$ & $\begin{array}{c}\text { Dens invaginatus } \\
\text { type }\end{array}$ & Treatment \\
\hline Fukuta et al., 1997 (7) & Maxilla & Lateral incisor & Type 3 & Type 1 & Observation \\
\hline McNamara et al., 1998 (8) & Maxilla & $\begin{array}{l}\text { Central and } \\
\text { ateral incisors }\end{array}$ & Type 2 and 3 & Types 2 and 3 & $\begin{array}{l}\text { Sealant placement + } \\
\text { endodontic therapy }\end{array}$ \\
\hline Lorena et al., 2003 (9) & Maxilla & Left lateral incisor & Type 1 & Type 2 & Observation \\
\hline Mupparapu et al., 2004 (10) & Maxilla & Right lateral incisor & Type 1 & Type 1 & Observation \\
\hline Tiku et al., 2007 (11) & Maxilla & Lateral incisor & Type 1 & Type 1 & Sealant placement \\
\hline Anthonappa et al., 2008 (12) & Maxilla & Right lateral incisor & Type 1 & Type 2 & Sealant placement \\
\hline Siraci et al., 2008 (13) & Mandible & Right central incisor & Type 1 & Type 2 & Sealant placement \\
\hline Sarraf-Shirazi et al., 2010 (14) & Maxilla & $\begin{array}{l}\text { Central incisors and } \\
\text { left lateral incisor }\end{array}$ & Type 3 & Type 1 & $\begin{array}{l}\text { Sealant placement }+ \\
\text { endodontic therapy } \\
\text { with apical MTA plug }\end{array}$ \\
\hline Present case & Mandible & Left central incisor & Type 1 & Type 1 & Sealant application \\
\hline
\end{tabular}


tooth was central incisor (Table 1).

Reports of the short root anomaly, mostly involved the maxillary incisors $(5,8)$. In the present case, this anomaly affected the mandibular central incisor which has not been reported so far. The presence of short root was not generalized as compared to other reported cases with underlying systemic abnormalities (16-18).

The occurrence of short roots is not due to resorption or any developmental disturbance of exogenous origin. The etiology of this root anomaly is not well understood. Several reports are of isolated cases of unknown origin, but a racial variation exists, with the greatest prevalence reported in Mongolian populations $(5,8)$. This racial variation, together with a strong familial background, indicates that this anomaly has a strong genetic influence (16). Apajalhti et al. (19) found a prevalence of $1.3 \%$ among healthy young adults. The male:female ratio is reported to be 1:3 (19). Presence of generalized short roots was found in combination with systemic conditions such as hypoparathyrodism, Stevens-Johnson syndrome, Rothmund-Thomson syndrome, exposure to irradiation and thalassaemia disorders (16-18). Desai et al. (20), reported a case of concomitant occurence of idiopathic generalized short root anomaly and microdontia, taurodontism of posterior teeth, obliterated pulp chambers, infected cyst and multiple dens invaginatus. McNamara et al. (8) reported a case with multiple anomalies, like short roots in the maxillary central incisors and premolars, talon cusps, dens invaginatus, low alveolar bone heights, tubercles of Carabelli in the maxillary first and second permanent molars, with pyramidal root morphology in three of the second permanent molars.

There are no reports in the literature on the symptoms of SRA and this anomaly should not be misdiagnosed with resorption (5). Its clinical significance is not stated.

Dens invaginatus is usually detected on routine radiographic examination and confirmed with a periapical radiograph. Radiographically, it appears as infolding of a radiopaque ribbon-like structure or pear shaped structure with equal density as enamel (3). Dens invaginatus has been classified into three categories according to the depth of invagination and communication with the periapical tissue or periodontal ligament $(3,21)$. Type 1 dens invaginatus is that when the invagination ends as a blind sac confined to the crown. In Type 2, the invagination extends apically beyond the external CEJ, ending as a blind sac and never reaching the periapical tissues. In Type 3, the invagination also extends beyond the CEJ and a second "apical foramen" is evident in either the periapical tissues or the periodontal ligament $(3,21)$. Talon cusp was classified by Hattab et al. (2) as follows. Type 1, true talon cusp is a morphologically well-delineated additional cusp that prominently projects from the palatal surface of a primary or permanent anterior tooth and extends at least half the distance from the CEJ to the incisal edge. Type 2, semi talon cusp, is an additional cusp of a millimeter or more but extending less than half the distance from the CEJ to the incisal edge. Type 3, trace talon, is enlarged or prominent cingula and their variations, i.e. conical, bifid, or tubercle-like. Radiographically, it may appear typically as a $\mathrm{V}$-shaped radiopaque, as for true talon and semi talon, or tubercle-like, starting from the cervical third of the crown (2). According to these classifications, in the present cases both the dens invaginatus and the talon cusp were classified as Type 1 .

Clinical problems encountered with talon cusp include occlusal interference, compromised esthetics, attrition, accidental cusp fracture, irritation to tongue during mastication and speech, temporomandibular joint pain, caries susceptibility because of developmental grooves on the talon cusp $(2,22,23)$. Dens invaginatus also has great clinical significance due to the possibility of the pulpal disease $(3,24,25)$. Pulpitis and pulp necrosis with or chronic periapical lesions are often associated with this anomaly without causing any clinical symptoms (8). In the present case, no such pathology was seen associated with dens invaginatus.

The treatment of talon cusp involves careful judgment and is dependent upon whether the cusp contains or is devoid of pulp tissue. There has been reported that talon cusp contains pulp horns of varying extensions (2). However, on radiographic examination, it is difficult to trace pulpal configuration inside the talon cusp because the cusp is superimposed over the affected tooth crown. The treatment objectives for the talon cusp occurring in mandibular incisors include sealing of developmental grooves, elimination of tongue irritation and correction of occlusal interference (13). In case of dens invaginatus, in order to prevent caries, pulp infection and premature tooth loss, this condition must be recognized early and the tooth must be prophylactically restored.

In the present case, as there were no problems or symptoms associated with the concurrent combination of dental anomalies, only sealing of the developmental 
groove was done to prevent occurrence of caries.

\section{RESUMO}

O incisivo central inferior permanente raramente é afetado por anomalias de forma envolvendo a coroa e a raiz. A co-ocorrência de múltiplas anomalias em um incisivo central inferior permanente é extremamente rara. Este artigo relata uma combinação concomitante incomum de múltiplas anomalias dentais afetando tanto a coroa quanto a raiz de um incisivo central inferior permanente - cúspide em garra (talon cusp), dens invaginatus, anomalia de raiz curta e macrodontia - que ainda não havia sido descrita na literatura. A condução do caso é descrita e suas implicações são discutidas. É importante que o dentista esteja familiarizado com essas entidades raras a fim de proporcionar diagnóstico e tratamento precisos, para os quais exames clínicos e radiográficos detalhados são extremamente importantes.

\section{REFERENCES}

1. Davis PJ, Brook AH. The presentation of talon cusp: diagnosis, clinical features, associations and possible etiology. Br Dent $\mathrm{J}$ 1986; 160:84-88.

2. Hattab FN, Yassin OM, Al-Nimri KS. Talon cusp in permanent dentition associated with other dental anomalies. Review of literature and reports of seven cases. ASDC J Dent Child 1996;63:368-376.

3. Hulsmann M. Dens invaginatus: aetiology, classification, prevalence, diagnosis and treatment considerations. Int Endod J 1997;30:79-90.

4. Mupparapu M, Singer SR. A rare presentation of dens invaginatus in a mandibular lateral incisor occurring concurrently with bilateral maxillary dens invaginatus: case report and a review of literature. Aust Dent J 2004;49:90-93.

5. Lind V. Short root anomaly. Scand J Dent Res 1972;80:85-93.

6. Neville BW, Damm DD, Allen CM, Bouquot JE. Oral and Maxillofacial pathology. 2nd ed. Saunders, 2005,73-74.

7. Fukuta Y, Totsuka M, Takeda Y, Yamamoto H. A central tubercle on the lingual surface of the upper lateral incisor: report of a case. J Nihon Univ Sch Dent 1997;39:86-88.

8. McNamara CM, Garvey MT, Winter GB. Root abnormalities, talon cusps, dens invaginati with reduced alveolar bone levels: case report. Int J Paediatr Dent 1998;8:41-45.

9. Lorena SC, Oliveira DT, Odellt EW. Multiple dental anomalies in the maxillary incisor region. J Oral Sci 2003;45:47-50.

10. Mupparapu M, Singer SR, Goodchild JH. Dens evaginatus and dens invaginatus in a maxillary lateral incisor: report of a rare occurrence and review of literature. Aust Dent J 2004;49:201-203.

11. Tiku A, Nadkarni UM, Damle SG. Management of two unusual cases of dens invaginatus and talon cusp associated with other dental anomalies. Int J Paediatr Dent 2007;17:178-185.

12. Anthonappa RP, Yiu CK, King NM. A novel combination of dens evaginatus and dens invaginatus in a single tooth - review of the literature and a case report. J Clin Pediatr Dent 2008;32:239-242.

13. Siraci E, Gungor HC, Cehreli ZC. Dens invaginatus and talon cusp co-occurring in a mandibular central incisor: a case report. J Dent Child 2008;75:177-180.

14. Sarraf-Shirazi A, Rezaiefar M, Forghani M. A rare case of multiple talon cusps in three siblings. Braz Dent J 2010;21:463-466.

15. Nagaveni NB, Umashankara KV, Sreedevi, Reddy BP, Radhika NB, Satisha TS. Multi-lobed mesiodens with a palatal talon cusp - a rare case report. Braz Dent J 2010;21:375-378.

16. Sauk JJ, Delaney JR. Taurodontism, diminished root formation and microcephalic dwarfism. Oral Surg Oral Med Oral Pathol 1973;36:231-235.

17. De Man K. Abnormal root development, probably due to erythema multiforme (Stevans-Johnson syndrome). Int J Oral Surg 1979;8:381-385.

18. Shaw L. Short root anomaly in a patient with severe short-limbed dwarfism. Int J Paediatr Dent 1995;5:249-252.

19. Apajalahti S, Holtta P, Turtola L, Pirinen S. Prevalence of shortroot anomaly in healthy young adults. Acta Odontol Scand 2002;60:56-61.

20. Desai RS, Vanaki SS, Puranik RS, Rashmi GS, Nidawani P. An unusual combination of idiopathic generalized short-root anomaly associated with microdontia, taurodontia, multiple dens invaginatus, obliterated pulp chambers and infected cyst: a case report. J Oral Pathol Med 2006;35:407-409.

21. Oehlers FA. Dens invaginatus I. Variations of the invagination process and associated anterior crown forms. Oral Surg Oral Med Oral Pathol 1957;10:1204-1218.

22. Hattab FN, Yassin OM, Al-Nimri KS. Talon cusp - clinical significance and management: case reports. Quintessence Int 1995;26:115-120.

23. Rani AK, Metgud S, Yakub SS, Pai U, Toshniwal NG, Bawaskar N. Endodontic and esthetic management of maxillary lateral incisor fused to a supernumerary tooth associated with a talon cusp by using spiral computed tomography as a diagnostic aid: a case report. J Endod 2010;36:345-349.

24. Er K, Kustarci A, Ozan U, Tasdemir T. Nonsurgical endodontic treatment of dens invaginatus in a mandibular premolar with large periradicular lesion. A case report. J Endod 2007;33:322-324.

25. Kodaira H, Motosuneya N, Fujihashi A, Ide M, Ohno K, Asada Y. Endodontic therapy for dens invaginatus in a mandibular second premolar. Jpn J Ped Dent 2008;46:360-366.

Received December 16, 2010 Accepted May 18, 2011 